\title{
愛生園及び敬愛園に於けろ癩性秃頭の統 計的觀察並びに秃頭度此較による氣候說
}

\author{
國立癩潦貝所星塚敬愛園（園長林文婎）
}

醫官永井健 兒

\author{
第 1 章 緒 \\ 第 2 章 各䖝型に於け万秃嘼 \\ 第 1 節 粘節瑱に於け万秃頭 \\ 第 2 節 神縃剩に於け万秃頭 \\ 第 3 節 班紋船に於け方秃頭

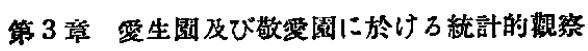 \\ 第 1 節 秃頭調查数並びに性別內摆 \\ 第 2 節 秃頭点者获型別 \\ 第 3 節 結節頛秃頭各程度の急者數

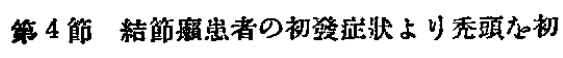

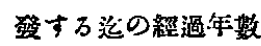

次

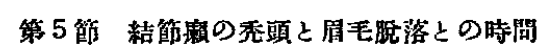
的關保

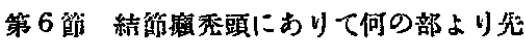
づ登落な始めしが

第 7 節 敬愛图の本土, 大点, 沖繩 3 地方 別剐者の秃頭

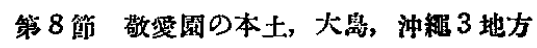
别点者の居毛脱洛の比較

第4 章 視括並びに秃頭度比绞による氣候說 第 5 章 結 踰

主要文㰻

\section{第 1 章 緒 言}

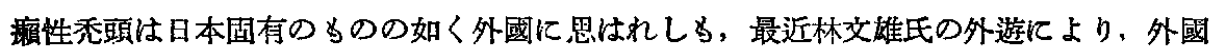
にる隹在する事を知れり。されどその數湛だ少くして，林氏「世界の救廎施設俔察報告」 によれば, フィリッピン $0 \%$, ジャバ $3.43 \%$ ，馬來 $0.08 \%$ ，スマト $0.4 \%$ ，パレスチナ 4 $\%$,ノールェー0\%, 南阿 $0.6 \%$, アルゼンチン $1.42 \%$, 北米合衆國 $1.43 \%$, 布哇 $0.22 \%$ なり。本邦に於ける瀨性秃頭は, 光田氏, 裳山, 石津兩氏, 大坂氏, 上川氏等の研究調查 されし處にして可成り多し。余は愛生園（昭和10年7月調查）及び敬愛園（昭和11年7月 調查)に於ける秃頭調查の結果を報告す。

\section{第 2 章各病型に於ける秃頭}

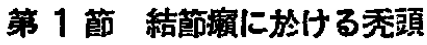

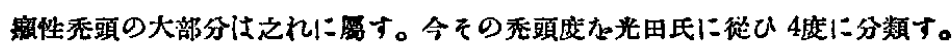

( 45 ) 


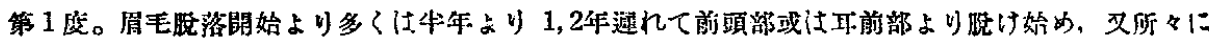
园形秃䪷に似たら形に薄毛となる程度。

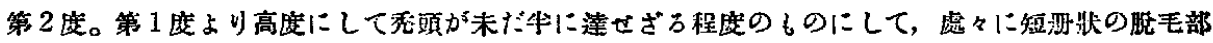

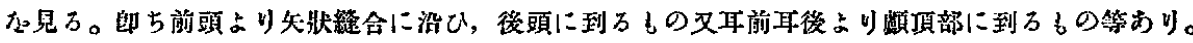

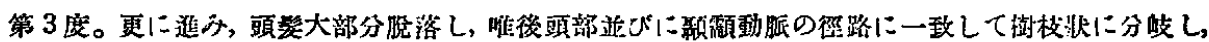

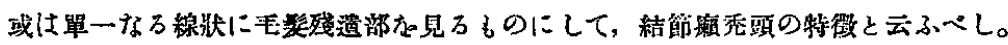

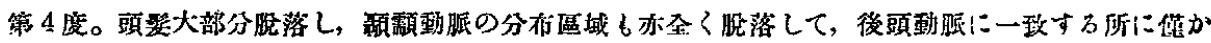
に殘存するものなり。

\section{第 2 節 神經贋に於ける秃頭}

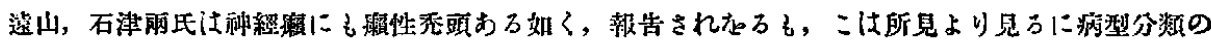
相異によるものなり。

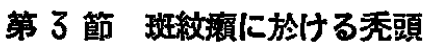

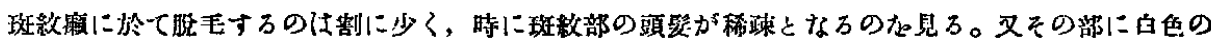

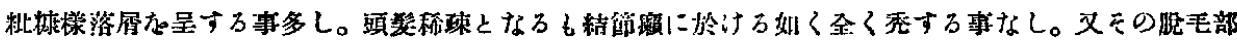

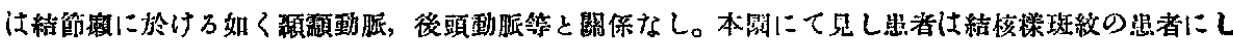

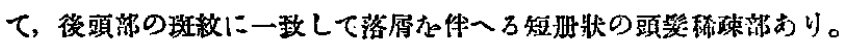

\section{第 3 章 愛生圆及び敬愛園に於ける統計的觀察}

\section{第 1 節 秃頭調查数並びに性別內譯}

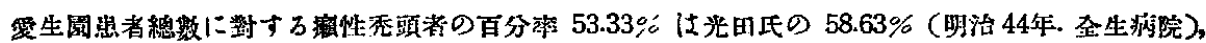

第 1 裴 秃頭誳查數並びに性別门譯

\begin{tabular}{|c|c|c|c|c|c|}
\hline & \multicolumn{2}{|c|}{ 數 释 } & 男 & 女 & 計 \\
\hline 舜 & \multicolumn{2}{|c|}{ 調 査 数 } & 780 & 270 & 1050 \\
\hline 生 & 秃 & 数 & 427 & 133 & 560 \\
\hline 園 & 頭 & $\%$ & 54.74 & 49.26 & 53.33 \\
\hline 敬 & \multicolumn{2}{|c|}{ 調 查 數 } & 292 & 126 & 418 \\
\hline 绥 & 秃 & 數 & 83 & 31 & 114 \\
\hline 園 & 頭 & $\%$ & 28.42 & 24.67 & 27.27 \\
\hline
\end{tabular}

及び石津氏の $62.1 \%$ 昭利 5年頃? 外島. 北部 兩保举院)より低深にして, 大坂氏の $21.74 \%$ （昭和 10年朝解更生國）よりは迢かに高管な り。又女は男より低察なる事は光田氏, 石津 氏, 大坂氏と一致すれる゙その差 $5.48 \%$ は光田 氏 $17.9 \%$ ，石津氏 $12.3 \%$ 小化して,大坂 氏 $5.14 \%$ まり稍、大なり。

敬爱園の秃頭沟 $27.27 \%$ 前記內地に於り 万調查より遥加に低慗にして, 更生图より稍、 高率なり。女は男より低率なれよ゙，その差

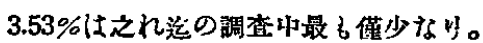




\section{第 2 蔀 秃頭患者病型別}

第 2 表 秀 頭 㭧者 瘕 型 別

\begin{tabular}{|c|c|c|c|c|c|c|c|c|c|c|c|c|c|c|}
\hline & 病节 & 型 & 結 & 節 & 鼠 & 玟 & 紋 & 癩 & 神 & 縒 & 翰 & 合 & & 部 \\
\hline \multirow[t]{2}{*}{ 愛 } & 性 & 別 & 男 & 女 & 計 & 男 & 女 & 話 & 愣 & 女 & 訪 & 男 & 女 & 垆 \\
\hline & \multicolumn{2}{|c|}{ 哭者數 } & 645 & 200 & 845 & 30 & 28 & 58 & 105 & 42 & 147 & 780 & 270 & 1050 \\
\hline 生 & 秃 & 数 & 426 & 132 & 558 & 1 & 1 & 2 & 0 & 0 & 0 & 427 & 133 & 560 \\
\hline 國 & 顒 & 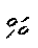 & 66.05 & 66.00 & 66.03 & 3.33 & 3.57 & 3.45 & 0 & 0 & 0 & 54.74 & 49.26 & 53.33 \\
\hline 敬 & \multicolumn{2}{|c|}{ 㕠者数 } & 183 & 61 & 244 & 43 & 30 & 73 & 66 & 35 & 101 & 292 & 126 & 418 \\
\hline 䌽 & 秃 & 数 & 82 & 30 & 112 & 1 & 1 & 2 & 0 & 0 & 0 & 83 & 31 & 114 \\
\hline 園 & 頍 & \%ó & 44.81 & 49.18 & 45.90 & 2.33 & 3.33 & 2.74 & 0 & 0 & 0 & 28.42 & 24.60 & 27.27 \\
\hline
\end{tabular}

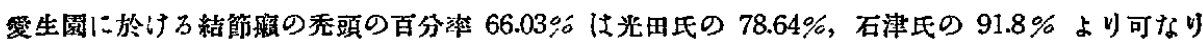

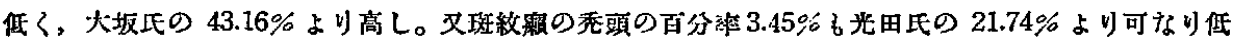

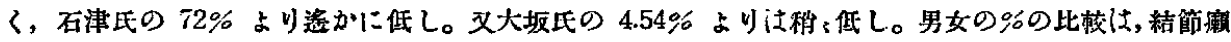

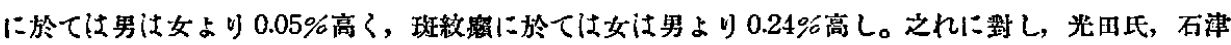

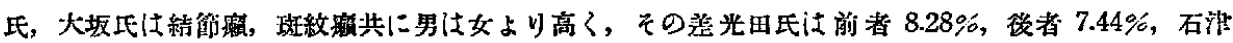

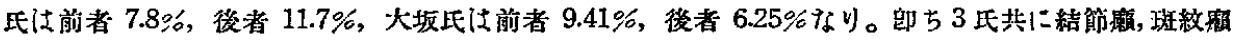

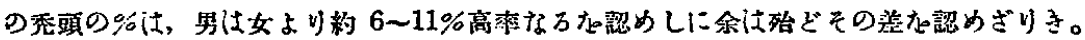

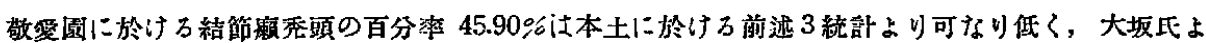

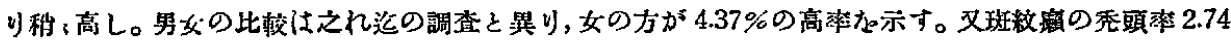
\%汒その調查數僅少なれども何れの調查より低染にして，女は男より $1.0 \%$ 高し。

\section{第 3 節 結篩境秃頭各程度の患者数}

光田氏の調查によれば男女共に第 3 度最も高篗にして $1,2,4$ の順なるが,雨图に於けろ余の調查で

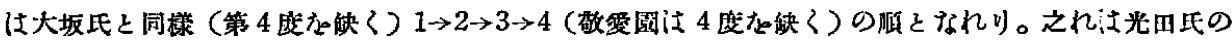

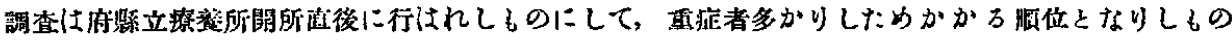
ならん。

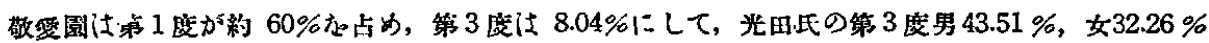

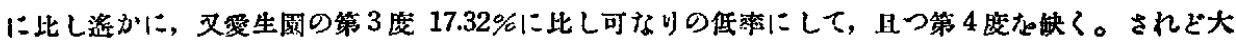
坂氏の第 1 度 $70.02 \%$ ，第 2 度 $24.36 \%$, 第 3 度 $5.62 \%$ に比すれ!゙稍、秃頍度重し。 
第 3 琵 結節瀬秃頭各程度の蚛省數

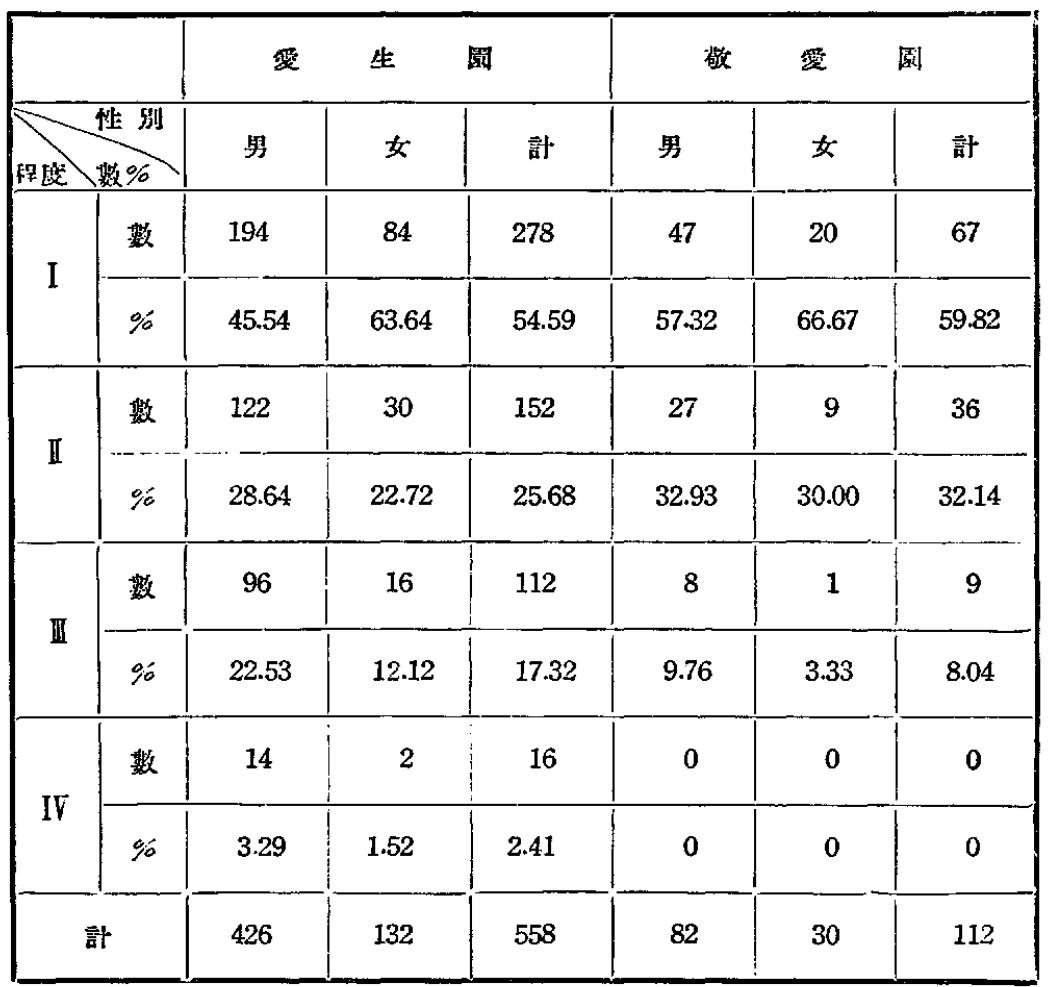

第 4 節 結節癩患者の初發症狀より秃頭を初㷋す

\section{ろ迄の經過年數}

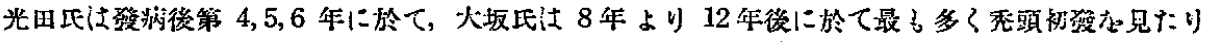

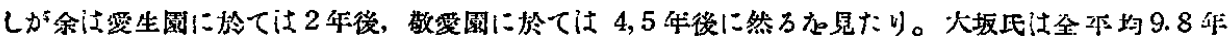

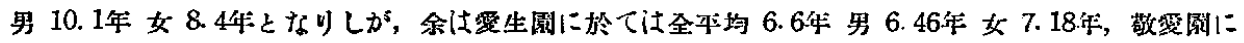

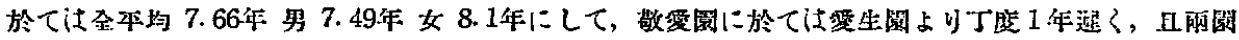

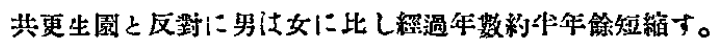

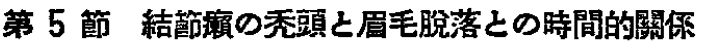

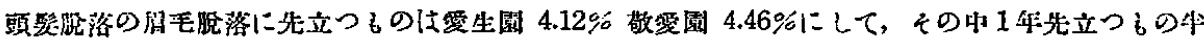

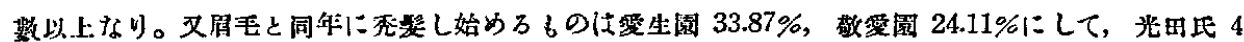

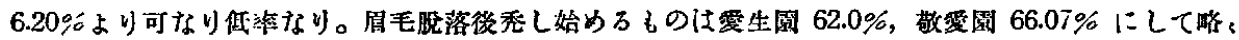

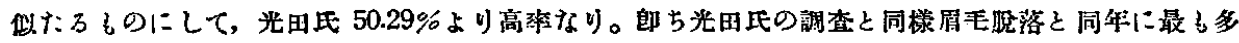

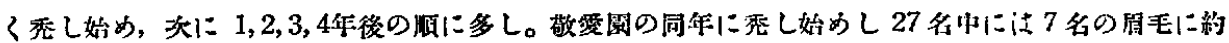
乎年还几し6のた台主。 


\begin{tabular}{|c|c|c|c|c|c|c|}
\hline 槒 & 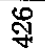 & พ్య & 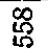 & ऽ & ஜి & $\stackrel{\vartheta}{\exists}$ \\
\hline 둥 & 0 & 0 & 0 & 10 & 0 & 10 \\
\hline 욥 & -1 & 0 & rt & 0 & 0 & 0 \\
\hline g & $\rightarrow$ & 0 & $\rightarrow$ & 0 & 0 & 0 \\
\hline ल & 0 & $r$ & 0 & 0 & 0 & 0 \\
\hline ణి & -1 & 0 & $\rightarrow$ & 0 & 0 & 0 \\
\hline giv & 0 & 0 & 0 & -1 & 0 & $r$ \\
\hline$\stackrel{\infty}{\infty}$ & 0 & $M$ & $r$ & 0 & 0 & 0 \\
\hline ড & 0 & 0 & 0 & 0 & 0 & 0 \\
\hline હ્ & 0 & 0 & 0 & 0 & 0 & 0 \\
\hline เ & 0 & 0 & 0 & -1 & 0 & $\rightarrow$ \\
\hline 心 & 0 & 0 & 0 & 0 & 0 & 0 \\
\hline ని & 0 & -1 & -1 & 0 & $r$ & $\rightarrow$ \\
\hline ญี & -1 & 0 & -1 & 0 & 0 & 0 \\
\hline$\vec{N}$ & $r$ & 0 & -1 & 0 & 0 & 0 \\
\hline 어 & $m$ & $r$ & $\forall$ & $\boldsymbol{N}$ & 0 & N \\
\hline 어 & $m$ & -1 & $\nabla$ & $\neg$ & 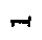 & N \\
\hline$\stackrel{\infty}{=}$ & $\nabla$ & -1 & 10 & 0 & N & N \\
\hline 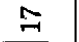 & $\nabla$ & L & $\sigma$ & $m$ & 0 & m \\
\hline $\mathscr{~}$ & $\infty$ & $\forall$ & $\stackrel{\Im}{\Im}$ & 0 & 0 & 0 \\
\hline 20 & $\nabla$ & -1 & in & N & v & $\forall$ \\
\hline 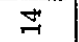 & 10 & 0 & in & N & 0 & N \\
\hline 9 & $\mathscr{M}$ & $-r$ & $\underset{ت}{\sharp}$ & $\rightarrow$ & 0 & -1 \\
\hline$\stackrel{\sim}{-1}$ & 옥 & $\omega$ & $\bigcup_{i=1}^{0}$ & N & 0 & N \\
\hline$\vec{F}$ & 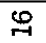 & $\forall$ & 尺ิ & $\forall$ & $r$ & in \\
\hline 옴 & 㓠 & $N$ & พิ & 10 & N & $N$ \\
\hline a & 고 & $r$ & $\stackrel{\infty}{\sim}$ & is & ৩ & $N$ \\
\hline$\infty$ & $\stackrel{\leftrightarrow}{*}$ & 0 & m & $N$ & $\rightarrow$ & $m$ \\
\hline$r$ & लొ & $\stackrel{M}{\rightarrow}$ & $g$ & $N$ & N & $\sigma$ \\
\hline 0 & $\stackrel{\text { ๙ }}{ }$ & a & 只 & $m$ & $m$ & 0 \\
\hline 10 & \& & 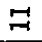 & in & $\omega$ & + & 음 \\
\hline$H$ & ๓ & $\stackrel{10}{\rightarrow}$ & $\underset{\forall}{*}$ & 옥 & $m$ & 9 \\
\hline$\infty$ & $\infty$ & $\stackrel{\overbrace{}}{\overbrace{}}$ & 운 & $\forall$ & N & $\infty$ \\
\hline N & $\stackrel{\varphi}{*}$ & $\ddot{9}$ & 욤 & $\nabla$ & + & $\infty$ \\
\hline$\rightarrow$ & คి & 을 & g & $\infty$ & 0 & $\varphi$ \\
\hline 登近 & $\mathbb{N}$ & N & 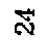 & $\infty$ & 0 & $\infty$ \\
\hline & 昤 & $\not$ & 袖 & 5 & $M$ & 荘保 \\
\hline & 龉 & 计 & 遌 & 湔 & 紫 & 避 \\
\hline
\end{tabular}

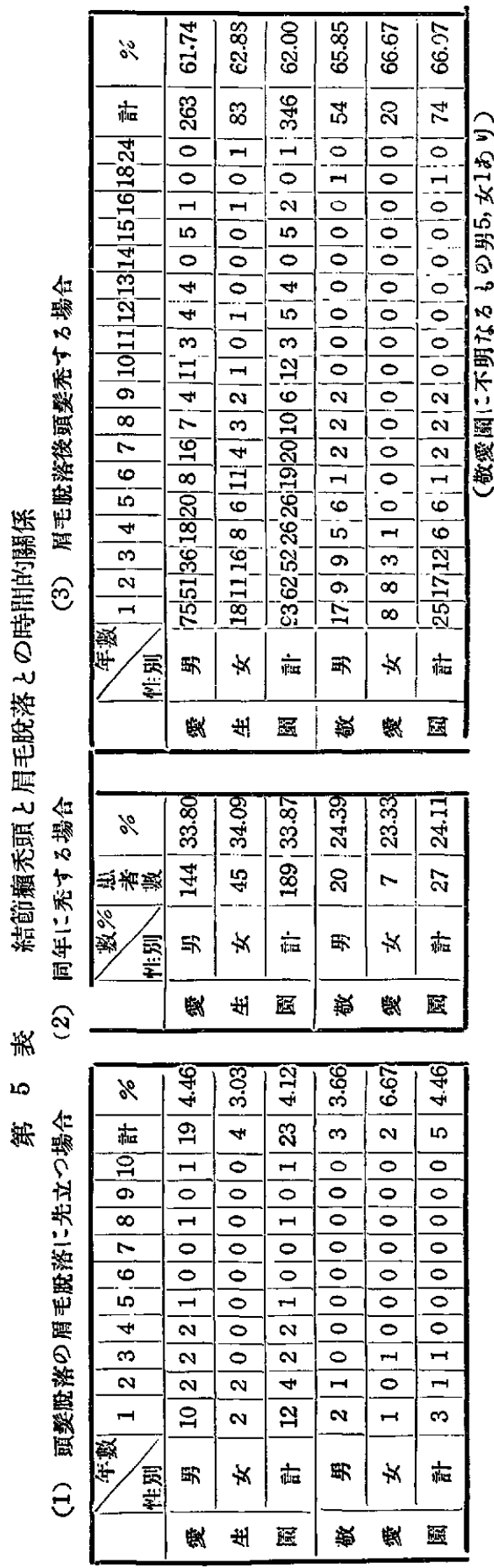

(49) 
永

茟

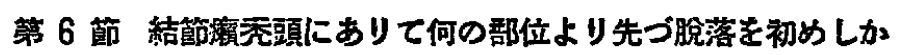

第 6 表 結笁瀨秃頭の初發部位

\begin{tabular}{|c|c|c|c|c|c|c|c|c|c|c|}
\hline & $\begin{array}{l}\text { 诜 } \\
5 \text { 列 }\end{array}$ & & 耳 囬 & 前 頡 & 㷒項 & 耳. 溇 & 後 頇 & 所 $?$ & 不 明 & 計 \\
\hline \multirow{2}{*}{ 悪 } & \multirow{2}{*}{ 男 } & 數 & 69 & 221 & 71 & 16 & 19 & 30 & 0 & 426 \\
\hline & & $\%$ & 16.19 & 51.88 & 16.67 & 3.76 & 4.46 & 7.04 & 0 & 100.0 \\
\hline 生 & \multirow{2}{*}{ 女 } & 渋 & 14 & 108 & 7 & 0 & 0 & 3 & 0 & 132 \\
\hline 网 & & $\%$ & 10.61 & 81.82 & 5.30 & 0 & 0 & 2.27 & 0 & 100.0 \\
\hline \multirow{2}{*}{ 敬 } & \multirow{2}{*}{ 男 } & 毁 & 22 & 47 & 6 & 1 & 5 & 0 & 1 & 82 \\
\hline & & $\%$ & 26.83 & 57.32 & 7.32 & 1.22 & 6.10 & 0 & 1.22 & 100.0 \\
\hline \multirow{2}{*}{ 国 } & \multirow{2}{*}{ 女 } & 数 & 2 & 28 & 0 & 0 & 0 & 0 & 0 & 30 \\
\hline & & gó & 6.67 & 93.33 & 0 & 0 & 0 & 0 & 0 & 100.0 \\
\hline
\end{tabular}

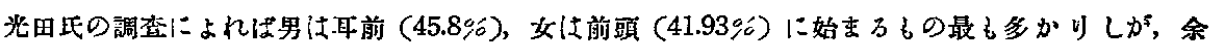

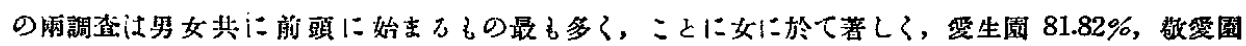
93.33\%の高莎庆示し，耳前频顶之れに次ぐ。

第 7 箅 敬愛園の本土, 大島, 沖繩地方別患者の秃頭

第 7 表 秃頭患替䇥型别

\begin{tabular}{|c|c|c|c|c|c|c|c|c|c|c|c|c|c|c|}
\hline & 雅 & & 綃 & 節 & 形籍 & 珫 & 紋 & 的颠 & 神 & 縔 & 懒 & \multicolumn{2}{|c|}{ 合 } & 計 \\
\hline & 性 & 別 & 男 & 女 & 訪 & 男 & 女 & 計 & 男 & 女 & 計 & 男 & 女 & 計 \\
\hline \multirow{2}{*}{ 本 } & \multicolumn{2}{|c|}{ 点者数 } & 83 & 24 & 107 & 9 & 6 & 15 & 22 & 6 & 28 & 114 & 36 & 150 \\
\hline & 秃 & 數 & 65 & 18 & 83 & 0 & 1 & 1 & 0 & 0 & 0 & 65 & 19 & 84 \\
\hline$t$ & 頭 & $\%$ & 78.31 & 75.0 & 77.57 & 0 & 16.67 & 6.67 & 0 & 0 & 0 & 57.02 & 52.78 & 56.00 \\
\hline
\end{tabular}




\begin{tabular}{|c|c|c|c|c|c|c|c|c|c|c|c|c|c|c|}
\hline \multirow{2}{*}{ 火 } & \multicolumn{2}{|c|}{ 㸃者数 } & 57 & 21 & 78 & 20 & 8 & 28 & 16 & 19 & 35 & 93 & 48 & 141 \\
\hline & 杰 & 数 & 9 & 8 & 17 & 0 & 0 & 0 & 0 & 0 & 0 & 9 & 8 & 17 \\
\hline 易 & 頭 & gá & 15.79 & 38.10 & 21.79 & 0 & 0 & 0 & 0 & 0 & 0 & 9.68 & 16.69 & 12.06 \\
\hline \multirow{2}{*}{ 油 } & \multicolumn{2}{|c|}{ 㤎者数 } & 43 & 16 & 59 & 14 & 16 & 30 & 28 & 10 & 38 & 85 & 42 & 127 \\
\hline & 秃 & 數 & 8 & 4 & 12 & 1 & 0 & 1 & 0 & 0 & 0 & 9 & 4 & 13 \\
\hline 絇 & 影 & $\%$ & 18.60 & 25.00 & 20.34 & 7.14 & 0 & 3.33 & 0 & 0 & 0 & 10.59 & 9.52 & 10.24 \\
\hline
\end{tabular}

第 8 表 結館瀨秃頭各程度の患者數

\begin{tabular}{|c|c|c|c|c|c|c|c|c|c|c|}
\hline \multirow{2}{*}{\multicolumn{2}{|c|}{ 程别 }} & \multicolumn{2}{|c|}{ 本 } & & \multicolumn{2}{|c|}{ 大 } & 晹 & \multicolumn{2}{|c|}{ 沖 } & 繩 \\
\hline & & 男 & 女 & 話 & 男 & 女 & 計 & 舁 & 女 & 함 \\
\hline \multirow{2}{*}{ I } & 數 & 33 & 11 & 44 & 6 & 5 & 11 & 8 & 4 & 12 \\
\hline & $q_{0}^{\prime}$ & 50.77 & 61.11 & 53.01 & 66.67 & 62.50 & 64.71 & 100.0 & 100.0 & 100.0 \\
\hline \multirow{2}{*}{ II } & 數 & 25 & 6 & 31 & 2 & 3 & 5 & 0 & 0 & 0 \\
\hline & $\%$ & 38.46 & 33.33 & 37.35 & 22.22 & 37.50 & 29.41 & 0 & 0 & 0 \\
\hline \multirow{2}{*}{$\mathbb{I I}$} & 數 & 7 & 1 & 8 & 1 & 0 & 1 & 0 & 0 & 0 \\
\hline & $\%$ & 10.77 & 5.56 & 9.64 & 11.11 & 0 & 5.88 & 0 & 0 & 0 \\
\hline \multirow{2}{*}{ IV } & 數 & 0 & 0 & 0 & 0 & 0 & 0 & 0 & 0 & 0 \\
\hline & $\%$ & 0 & 0 & 0 & 0 & 0 & 0 & 0 & 0 & 0 \\
\hline \multicolumn{2}{|c|}{ 計 } & 65 & 18 & 83 & 9 & 8 & 17 & 8 & 4 & 12 \\
\hline
\end{tabular}

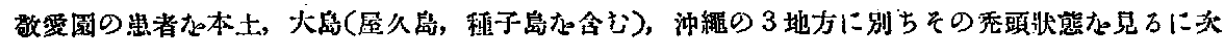
の如 L。

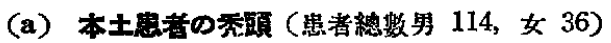

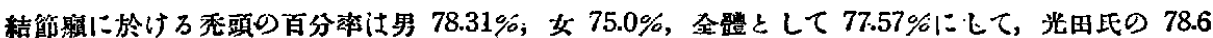
( 51 ) 


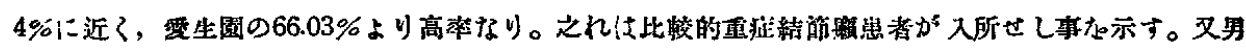

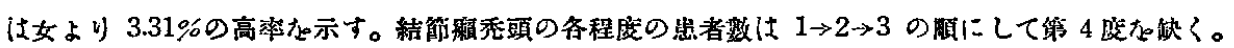

（b）大息患者の秃頚 (患活總數 男 93 ，女 48)

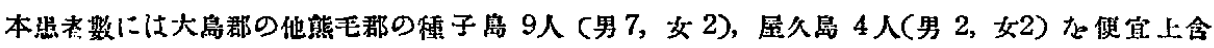

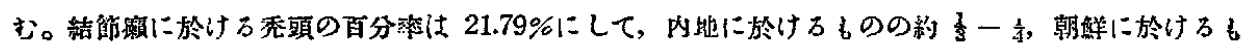

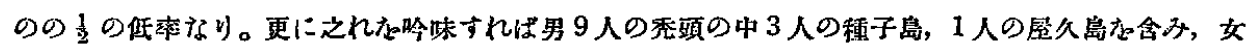

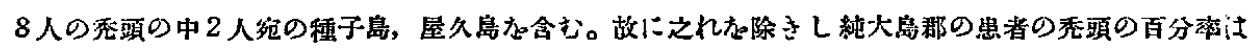
$13.64 \%$ ，男 $10.20 \%$ ，女 $23.53 \%$ となる。

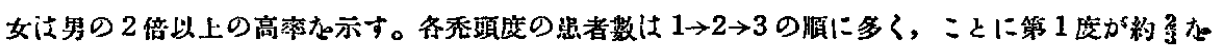
占め, 秃頭の视暖なることな示す。

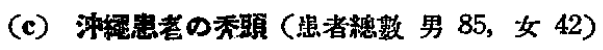

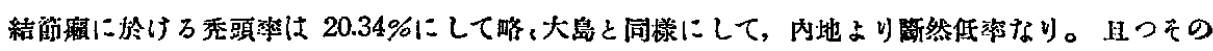

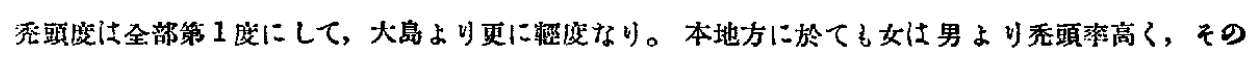
差6.40\%标り。

第 8 莭 敬受園の本土, 大島, 沖繩了地方別患者の眉毛脫落の比較

第 9 表 結節瀨の眉丰脫落程度別

\begin{tabular}{|c|c|c|c|c|c|c|c|c|c|c|}
\hline 程 & \multicolumn{2}{|c|}{ I } & \multicolumn{2}{|c|}{ II } & \multicolumn{2}{|c|}{ III } & \multicolumn{2}{|c|}{ IV } & \multicolumn{2}{|c|}{ 計 } \\
\hline 馠地 & 数 & $\%$ & 數 & $\%$ & 数 & $\%$ & 数 & $\%$ & 數 & $\%$ \\
\hline $\begin{array}{l}\text { 本 } \\
\text { 土 }(107)\end{array}$ & 14 & 13.08 & 19 & 17.76 & 42 & 39.25 & 30 & 28.04 & 105 & 98.13 \\
\hline 㞭 & 33 & 42.31 & 8 & 10.26 & 7 & 8.97 & 8 & 10.26 & 56 & 71.79 \\
\hline $\begin{array}{l}\text { 油 (59) } \\
\text { 繶 }\end{array}$ & 24 & 40.68 & 7 & 11.86 & 8 & 13.56 & 5 & 8.47 & 44 & 74.58 \\
\hline 訣 & 71 & 29.10 & 34 & 13.93 & 57 & 23.36 & 43 & 17.62 & 205 & 84.02 \\
\hline
\end{tabular}

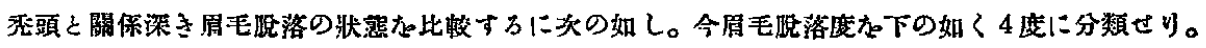

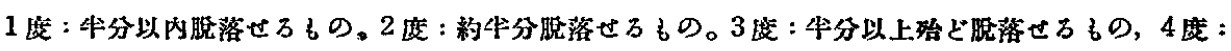
企く脫落せる6の。

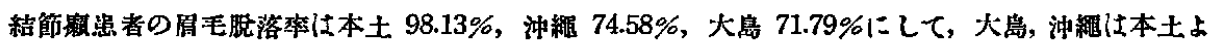

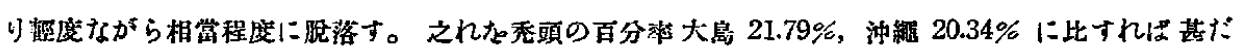
滈管なり。

第 4章 總括並びに秃頭度比較による氣候說 


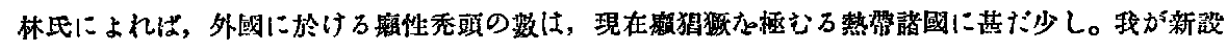

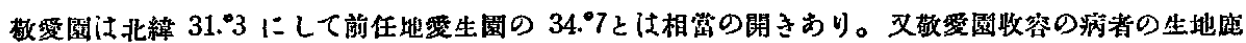
兒島本土,大島, 沖䋸にてに大體表の如し。

第 10 表

\begin{tabular}{|c|c|c|c|c|}
\hline 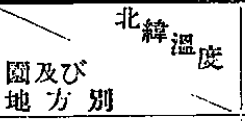 & 北 & $\begin{array}{l}\text { 平均溫度 } \\
\text { (炤和10住) }\end{array}$ & $\begin{array}{c}\text { 最高一一最庭 } \\
\text { (昭和10年) }\end{array}$ & 较 \\
\hline 愛 生 图 & $34 . \bullet 7$ & $14 .^{\circ} 7$ & $35.9-\left(-6^{\circ} 1\right)$ & $42 .^{\circ} 0$ \\
\hline 敬 愛 園 & $31 .^{\bullet} 3$ & & & \\
\hline 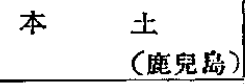 & $31^{\circ}-32^{\circ}$ & $16 .^{\circ 9}$ & $34 .^{\circ} 6-\left(-4 .^{\circ} 3\right)$ & $38 . \bullet 9$ \\
\hline $\begin{array}{ll}\text { 艮 } & \\
(\text { 名 } & \text { 濑) }\end{array}$ & $28 .^{\circ} 0$ & $21 .^{\circ} 0$ & $34^{\circ} .8-6^{\circ} .0$ & $28 .^{\circ} 2$ \\
\hline 沖 繩 (那硼) & $26 .^{\circ} 0$ & 22.0 & $31^{\circ} .5-10.0$ & $21 .^{\circ} 5$ \\
\hline
\end{tabular}

第 11 表

\begin{tabular}{|c|c|c|c|c|c|c|c|c|c|c|c|c|c|c|c|c|c|c|}
\hline \multirow{3}{*}{\multicolumn{2}{|c|}{ 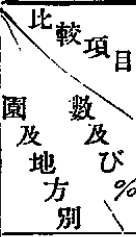 }} & \multicolumn{3}{|c|}{$\begin{array}{c}\text { a) } \\
\text { 全入图者秃頭 } \\
\text { 比較 }\end{array}$} & \multicolumn{3}{|c|}{$\begin{array}{l}\text { b) 絬節型に於け } \\
\text { 万秃頭比較 }\end{array}$} & \multicolumn{8}{|c|}{ 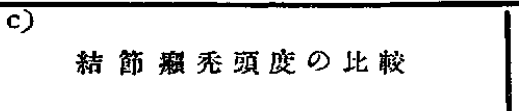 } & \multicolumn{3}{|c|}{ d) } \\
\hline & & \multirow{2}{*}{$\begin{array}{l}\text { 全 } \\
\text { 入 } \\
\text { 闧 } \\
\text { 者 }\end{array}$} & \multirow{2}{*}{ 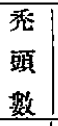 } & \multirow{2}{*}{$\%$} & \multirow{2}{*}{ 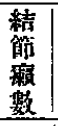 } & \multirow{2}{*}{$\begin{array}{l}\text { 乘 } \\
\text { 頭 } \\
\text { 数 }\end{array}$} & \multirow{2}{*}{$\%$} & \multicolumn{2}{|c|}{$I$} & \multicolumn{2}{|c|}{ II } & \multicolumn{2}{|c|}{ II } & \multicolumn{2}{|c|}{ IV } & \multirow{2}{*}{\multicolumn{2}{|c|}{ 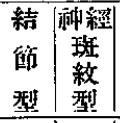 }} & \multirow{2}{*}{ 此 } \\
\hline & & & & & & & & 數 & $\%$ & 数 & $\%$ & 數 & 90 & 碓 & $\%$ & & & \\
\hline \multicolumn{2}{|c|}{ 愛 生 圆 } & 1050 & 560 & 53.33 & 845 & 558 & 66.03 & 278 & 54.59 & 152 & 25.68 & 112 & 17.32 & 16 & 2.41 & 845 & 205 & $4.1: 1$ \\
\hline \multicolumn{2}{|c|}{ 敬授 圆 } & 418 & 114 & 27.27 & 244 & 112 & 45.90 & 67 & 59.82 & 36 & 32.14 & 9 & 8.04 & 0 & 0 & 244 & 174 & $1.4: 1$ \\
\hline \multirow{2}{*}{ 内 } & 本土 & 150 & 84 & 56.00 & 107 & 83 & 77.59 & 44 & 53.01 & 31 & 37.35 & 8 & 9.64 & 0 & 0 & 107 & 33 & $3.2: 1$ \\
\hline & 大島 & 141 & 17 & 12.06 & 78 & 17 & 21.79 & 11 & 64.71 & 5 & 29.41 & 1 & 5.88 & 0 & 0 & 78 & 63 & $1.2: 1$ \\
\hline 謤 & 沖繩 & 127 & 13 & 10.24 & 59 & 12 & 20.34 & 12 & 100.0 & 0 & 0 & 0 & 0 & 0 & 0 & 59 & 68 & $1: 1.2$ \\
\hline \multicolumn{2}{|c|}{ 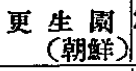 } & 2699 & 587 & 21.74 & 1353 & 584 & 43.16 & & & & & & & & & & & \\
\hline \multicolumn{2}{|c|}{$\begin{array}{l}\text { 采 生 院 } \\
\text { (臺灣) }\end{array}$} & 119 & 25 & 21.01 & & & & & & & & & & & & & & \\
\hline \multicolumn{2}{|c|}{ 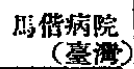 } & 54 & 7 & 12.96 & & & & & & & & & & & & & & \\
\hline
\end{tabular}

( 53 ) 


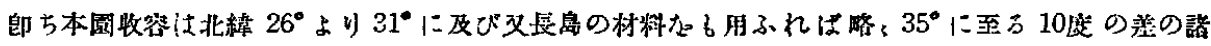

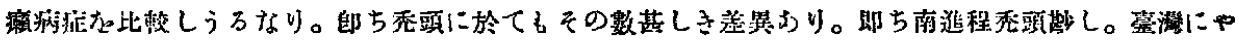

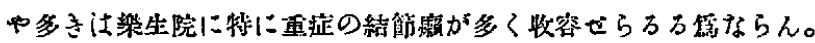

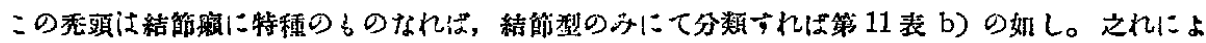

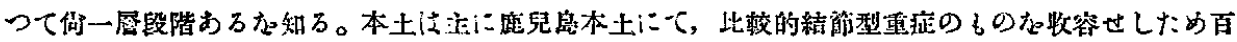
分管高し。

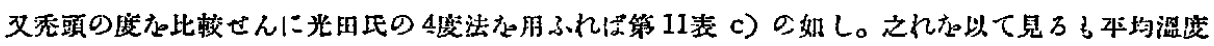

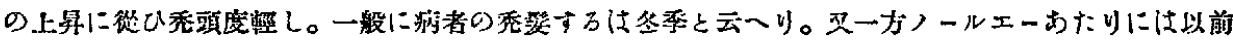

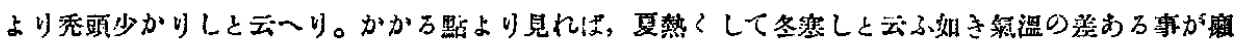

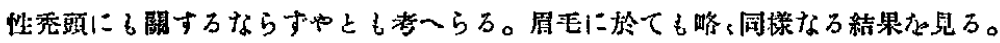

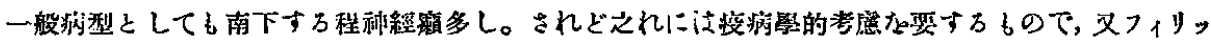

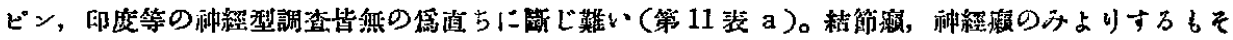

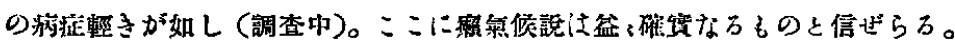

\section{第 5 章 結 諭}

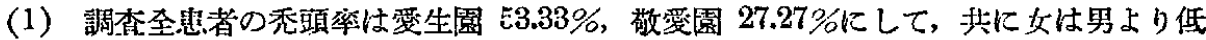
率枋り。

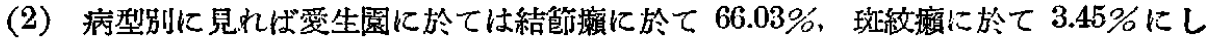
て，男女夙に羕は殆どなし。敬愛園は結節瀨に於て45.90\%にして，本土の何れの統計より

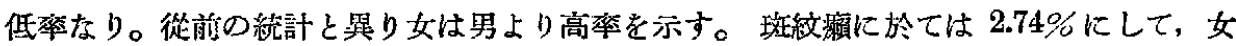

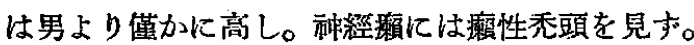

（3）秃頭度别に見れば兩園と第 1 度が過牛數を占め，乙の數は $1 \rightarrow 2 \rightarrow 3 \rightarrow 4$ の順とな り、敬受園は第 4 度を缺き、軖落なり。

（4）筑病より秃髮開始迄の經渦年數は愛生園に於ては 2 年, 敬愛園に於ては 4,5 年の むの最多し。

（5）秃頭と眉毛脫落との時間的關係は同年に始亲るすの最り多く，之れに次ぎ眉毛脫 落開始後 1 年, 2 年, 3 年の䐓に多く秃し始める。

（6）結節癩秃頭にありては男女拱に前頭部より秃し始めるるの最り多く、ことに女に著 し。耳前, 顱媔之れに次ぐ。

（7）敬愛園の本土，大島，沖繩 3 地方別患者の結節癩に於ける秃頭率は本土 77.57\%に

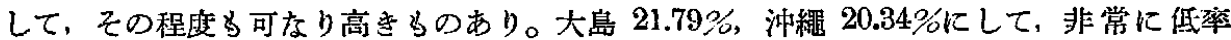
にして，その程度り輕くことに沖繩は奎部第 1 度なり。 
（8）瀨性秃頭は南方に行くに從ひ少く，且つその程度輕し。郎ち氣候が瀨性秃頭に對 し大なる影響を有すと考へらる。

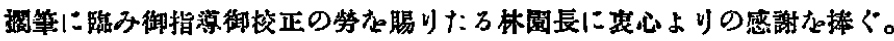

\section{文留}

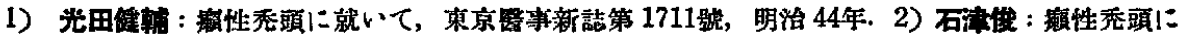

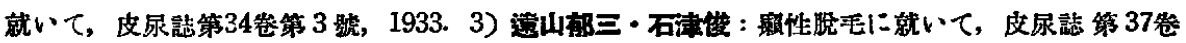

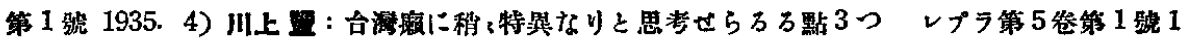

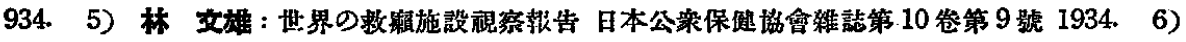

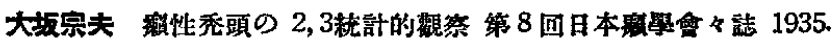

（昭和 11 年 12月 20日婿稿） 


\section{STATISTICAL STUDY ON LEPROSY ALOPECIA IN THE AISEIEN AND THE KEIAIEN.}

\section{Dr. Kenji Nagai}

(Keiaien National Leprosorium, Kagoshimaken, Japan)

Foreign physicians visiting japanese leprosoria used to say that the alopecia leprosa is peculiar sympton in Japan, not seen in other countries. But Dr. Fumio Hayashi, in his world study tour in 1933, seeing some alopecia leprosa cases in several countries, though not so many and so severe as in Japan, witnessed that it was not peculiar in Japan.

He dared to say that the cold climate would play an important role in causing leprosy alopecia, as the hotter the country is, the smaller the number and the slighter the grade of baldness is.

As the newly opened national leprosorium Keiaien is located far south from the Aiseien, the author compared the alopecia in these two colonies.

1) The percentages of leprotic alopecia are respectively $53.33 \%$ in 1050 inmates in the Aiseien and $27.27 \%$ in 418 in the Keiaien, and classifying by leprosy types, $66.03 \%$ in $845 \mathrm{C}$ cases in the Aiseien and $45.90 \%$ in $244 \mathrm{C}$ cases in the Keiaien. Small number of alopecia maculosa is not refered in the later numberes.

2) Classifying alopecia by the grade in four, the severer the grade is, the smaller becomes the number as $1>2>3>4$.

As in the Keiaien, each one third of the inmates was admitted from three different parts of southen Japan on different latitudes as the table following, it is noteworthy to compare the number and the grade of alopecia in three groups.

Alopecia and Temperature

\begin{tabular}{|c|c|c|c|c|c|c|c|c|}
\hline $\begin{array}{l}\text { Number of } \\
\text { Alopecia (c) }\end{array}$ & \multicolumn{4}{|c|}{ Grades of a'opecia } & N. L. & $\begin{array}{l}\text { Av. Temp. } \\
\text { (1935) }\end{array}$ & $\underset{\mathrm{T} .}{\operatorname{Max} \text {.Min. }}$ & $\begin{array}{l}\text { Diff.of Max } \\
\text { a. Min. }\end{array}$ \\
\hline $\begin{array}{lc}\text { Aiseien } & 558 \\
& (66.03 \%)\end{array}$ & $\begin{array}{c}278 \\
(54.59 \% 6)\end{array}$ & $\begin{array}{c}152 \\
(25.68 \% 0)\end{array}$ & $\begin{array}{c}112 \\
(17.32 \%)\end{array}$ & $\begin{array}{c}16 \\
(2.41 \%)\end{array}$ & 34.7 & 14.7 & $35.9-(-6.1)$ & $4: 0$ \\
\hline $\begin{array}{lc}\text { Keiaien } & 112 \\
(45.90 \%)\end{array}$ & $\begin{array}{c}67 \\
(59.82 \%)\end{array}$ & $\begin{array}{c}36 \\
(32.14 \%)\end{array}$ & $\begin{array}{c}9 \\
(8.04 \% 6)\end{array}$ & 0 & 31.3 & & & \\
\hline${ }_{(77.57 \%)}^{\text {Kyushu }}$ & $\begin{array}{c}44 \\
(53.01 \%)\end{array}$ & $\begin{array}{c}31 \\
(37.35 \% 6)\end{array}$ & $\begin{array}{c}8 \\
(9.64 ; 6)\end{array}$ & 0 & $31^{\circ}-34^{\circ}$ & 16.9 & $34.6(-4.3)$ & 38.9 \\
\hline $\begin{array}{l}\text { Oshima } \\
\text { archi. } \\
\text { ar. }\end{array}$ & $\begin{array}{c}11 \\
(64.71, a)\end{array}$ & $\begin{array}{c}5 \\
(29.41 \%)\end{array}$ & $\stackrel{1}{(5.88 \%)}$ & 0 & 28.0 & 21.0 & $34.8-6.6$ & 28.2 \\
\hline $\begin{array}{l}\text { Okinawa } 12 \\
\text { archi. (20.34\%) }\end{array}$ & $\begin{array}{c}12 \\
(100.0 \%)\end{array}$ & 0 & 0 & 0 & 26.0 & 22.0 & $31.5-10^{\circ} .1$ & 21.5 \\
\hline
\end{tabular}


It is a remarkable fact that the lower the north latitudes, in other words, the hotter the climates, the smaller becomes the number and the slighter the grade, and it confirms Dr. Hayashi's climate theory in leprosy alopecia.

But it was said that there were few alopecia cases in Norway when leprosy was prevalent there, the difference of temperature maximum and minimum would play a role in this problem.

3) Other data found:

a. The time when most of the cases begin falling hair is the sacond year since the leprosy outbreak in the Aiseien, and the fourth or fifth year in the Keiaien.

b. Alopecia and fall of the eyebrows begin in the same time in $33.87 \%$ in the Aiseien and $24.11 \%$ in the Koiaien, while in $62.0 \%$ in the Aiseien and $66.07 \%$ in the Keiaien alopecia begins after the begining of the fall of eyebrows.

c. Usually alopecia begins from forehead, specially by female. By male it begins oft from the front part of the ears. (Abstracted by the author) 